\title{
The northernmost discovery of a Miocene proboscidean bone in Europe
}

\section{Salonen, Jaakko Sakari}

2016

Salonen, J S , Saarinen , J J , Miettinen , A I , Hirvas , H, Usoltseva , M , Fortelius , H L M \& Sorsa , M 2016 , ' The northernmost discovery of a Miocene proboscidean bone in Europe

', Palaeogeography, Palaeoclimatology, Palaeoecology , vol. 454 , pp. 202-211 . https://doi.org/10.1016/j.palaeo.20

http://hdl.handle.net/10138/237339

https://doi.org/10.1016/j.palaeo.2016.04.034

cc_by_nc_nd

Downloaded from Helda, University of Helsinki institutional repository.

This is an electronic reprint of the original article.

This reprint may differ from the original in pagination and typographic detail.

Please cite the original version. 


\section{The northernmost discovery of a Miocene proboscidean bone in Europe}

2

3 J. Sakari Salonen ${ }^{1}$, Juha Saarinen ${ }^{1,2}$, Arto Miettinen ${ }^{1,3}$, Heikki Hirvas ${ }^{4}$, Marina Usoltseva ${ }^{5}$,

4 Mikael Fortelius $^{1,6}$, Marja Sorsa ${ }^{7}$

5

61 Department of Geosciences and Geography, PO Box 64, FI-00014 University of Helsinki,

$7 \quad$ Finland

82 Natural History Museum, London, Cromwell Road, London SW7 5BD, UK

93 Norwegian Polar Institute, Fram Centre, NO-9296 Tromsø, Norway

104 Geological Survey of Finland, PO Box 96, FI-02151 Espoo, Finland

115 Limnological Institute of the Siberian Branch of the Russian Academy of Sciences, Ulan-

12 Batorskaya 3, 664033 Irkutsk, Russia

136 Centre for Ecological and Evolutionary Synthesis, Dept. of Biosciences, University of Oslo,

14 PO Box 1066 Blindern, NO-0316 Oslo, Norway

157 Department of Genetics, PL 56, 00014 University of Helsinki, Finland

16 *Corresponding author. E-mail: sakari.salonen@helsinki.fi.Phone: +358-29-4151577.

17

18

19

20

21

22

23

24

25

26 
ABSTRACT

We discuss a proboscidean bone fragment discovered in southern Finland, including the morphological analysis of the bone, as well as pollen and diatom analyses from sediment contained in the marrow cavity. Preliminary analysis of the bone suggested petrification and thus an apparently old age, while the microfossil assemblages include numerous unequivocally pre-Quaternary pollen, spore, and diatom types. A Miocene age for the bone is determined based on the presence of the diatom genus Alveolophora, indicating a minimum age of $5 \mathrm{Ma}$, and based on the earliest appearance of proboscideans outside Africa, setting a maximum age of 19 Ma. Based on morphology, the bone is determined as a partial humerus of the left foreleg of a large proboscidean. The bone is tentatively assigned to cf. Deinotherium sp., which is consistent with the diatom-based minimum age. The pollen assemblage is rich in spores of shoreline pteridophytes, while the diatom assemblage is also consistent with a shoreline freshwater environment, suggesting that the bone was deposited post-mortem near the shore of a lake or a stream. Miocene sediments do not currently exist in southern Finland or in the near vicinity. This implies that the bone has been transported over a considerable distance. Due to the discovery of the bone in early-Holocene Baltic Sea clay, the final transport phase and deposition must have taken place via iceberg rafting. This was likely preceded by one or more phases of glacial and/or glacio-fluvial transport. While we are unable to conclusive ascertain the region of origin, the alkaline composition of the contained sediment and diatoms point towards the Russian Plain region in the east. This specimen represents the oldest mammalian bone discovered in Finland and the northernmost discovery of a Miocene proboscidean bone in Europe.

50

51 Keywords: Finland, Deinotherium, Neogene, pollen, diatoms, environmental reconstruction 
INTRODUCTION

55

\section{Discovery of the bone}

57

In about 1960, a 25-cm-long bone fragment was found during autumn gardening at a lake-shore "summer house" situated in the municipality of Suomusjärvi, southern Finland (Fig. 1a-b). The finder, young biology student Marja Sorsa, discovered the bone fragment in sandy clay at a depth of about $50-60 \mathrm{~cm}$. The piece, first thought to be a remnant of a ploughing ox or a piece of a mammoth, was stored in a cardboard box in a garden shelter. The bone was later removed from its original finding site into a city garage storage and forgotten until finally in 2006, the finder (M.S.) presented the bone to professor Mikael Fortelius at the meeting of the Finnish Academy of Science and Letters. The bone was identified as a partial humerus of the left foreleg of a proboscidean. Due to its big size and structure, the original hypothesis was that the bone belongs to a proboscidean of Quaternary age, as all fossil mammal specimens previously discovered in Finland have been of late Quaternary or Holocene age, including the ten finds of woolly mammoth (e.g. Ukkonen et al., 2011) the oldest of which is dated to ca. $120 \mathrm{ka}$ (Ukkonen et al., 2010). However, the Suomusjärvi bone raised special interest as it was partly eroded and heavy, possibly indicating a petrification and thus a greater age. As the then available information was too sparse for inferring the age of the bone, we performed sedimentological and microfossil analyses (pollen, diatoms) in order to estimate the age and the depositional environment of the bone. In addition, the morphology and structure of the bone were thoroughly investigated.

[Figure 1] 
81 Finland is situated at the centre of the area covered by the Scandinavian Ice Sheet during the

82 Late Pleistocene, and thus in the vicinity of large periglacial centres of terrestrial mammals in

83 Europe and Siberia (Ukkonen, 2001). The Finnish geological setting is mainly composed of

84 Precambrian bedrock (with some small bits of Palaeozoic), stripped clean of younger layers by repeated glacial erosion during the Pleistocene, with the crystalline Precambrian bedrock typically only overlain by glacial deposits of the last glaciation. As the repeated glaciations have generated a landscape consisting of bedrock that is up to $3.2 \mathrm{Ga}$ old and a sediment layer less than $20 \mathrm{ka}$ old, practically no fossil bearing deposits have survived (Ukkonen, 2001). For example, deposits of the Neogene or the Palaeogene do not exist in southern Finland. In contrast, isolated remains of sediments representing these periods have been preserved in northern Finland, where Pleistocene glacial erosion has been weaker due to the location closer to the Fennoscandian ice divide. These deposits include the Palaeogene marine clay at Akanvaara, as well as a Neogene freshwater diatomite in Naruskajärvi (Hirvas and Tynni, 1976; Tynni, 1982; Rasmussen et al., 2008).

The site of bone discovery is situated in the west of Lake Enäjärvi, in the municipality of Suomusjärvi, in southern Finland $\left(60^{\circ} 17^{\prime} 47^{\prime \prime} \mathrm{N} 23^{\circ} 38^{\prime} 28^{\prime \prime}\right.$ ) (Fig. 1a). Today the site is located $60 \mathrm{~m}$ above the present sea level. The bone was found in clay sediment covered by a thin agricultural soil, at a depth of about $50 \mathrm{~cm}$. The depth and character of the clay layer was confirmed in a later excavation in 2006 (Fig. 1c). The area was released from the late Weichselian ice sheet at the onset of the Holocene around 11,500 years ago (Saarnisto and Saarinen, 2001), and the site of discovery is located between the Salpausselkä II and III icemarginal formations. In the Baltic Sea history, this timing corresponds with the Yoldia Sea stage, which started when the Baltic Ice Lake was drained to ocean level through channels in central Sweden and water level dropped around $25 \mathrm{~m}$ in the Baltic basin ca. 11,700 years ago (e.g. Björck, 1995). During the Yoldia Sea stage, clayish sediments and ice-rafted material from icebergs accumulated at the site within the water depth of around $60 \mathrm{~m}$ at this time. 


\section{Outline of this study}

111 Examination of the bone revealed hard-packed brownish silty sediment preserved in the bone marrow cavity (Fig. 1b,d). As microfossils such as pollen and diatoms often contain useful chronological and environmental indicators, the preservation of the sediment thus presents an opportunity to provide further constrains on the history of the bone, both in terms of its age and its geographic origin, as well as the systematic determination of the animal.

Here we present the results of a multidisciplinary investigation into the origin of the Suomusjärvi bone, including (A) the analysis of the bone fragment itself, (B) pollen and diatom analyses for the sediment contained within the bone, and (C) consideration of the geological context and processes in the setting in which the bone was found. In assessing the results we especially focus on the following four questions:

1. Is it possible to provide a species or genus level identification for the animal based on bone morphology and size?

2. Is it possible to narrow down the age of the bone based on the species identification

\section{METHODS}

\section{Analysis of the bone}


136 The specimen from Suomusjärvi is confirmed to be a fragment of a left humerus diaphysis of a 137 proboscidean. We describe the specimen systematically and compare it with other published 138 proboscidean humeri from the Neogene of Europe. The preservation of the specimen is 139 discussed. Linear osteometric measurements were taken on $1 \mathrm{~mm}$ precision with a digital 140 caliper, and minimum circumference was measured with a flexible measuring tape. The 141 measurements were taken following Göhlich (1998) and Huttunen and Göhlich (2002). 142 Minimum depth of the diaphysis was measured from the location of minimum width in the 143 bone. The specimen was weighed at $1 \mathrm{~g}$ precision using a digital scale.

\section{Sedimentological analysis}

The composition of the fine fraction sediment preserved in the bone was carried out by the Field Emission Scanning Electron Microscope (SEM) method in the Research Laboratory of the Geological Survey of Finland.

\section{Pollen analysis}

152

153 A pollen sample was prepared from ca. $1 \mathrm{~cm}^{3}$ of sediment using $\mathrm{KOH}$ and $\mathrm{HF}$ treatments 154 (Moore et al., 1991). The entire residue was mounted in silicone oil on six slides and analysed using a light microscope. The pollen were identified using literature on modern European (Moore et al., 1991; Reille, 1992) and Asian (Wang et al., 1997) pollen types, supplemented with literature on European Neogene palynology (Shatilova and Stuchlik, 1996; Grímsson and Zetter, 2011; Grímsson et al., 2011).

\section{Diatom analysis}


162 The diatom sample of ca. $1 \mathrm{~cm}^{3}$ was prepared using standard methods (Battarbee, 1986). A

163 Nikon microscope with 1000x magnification was used for the identification of diatoms. One

164 hundred valves were counted in the sample. The taxonomy is based on the following sources:

165 Mölder and Tynni (1967-1973), Tynni (1975-1980), Ross et al. (1979), Krammer and Lange-

166 Bertalot (1986-1991), and Usoltseva et al. (2013).

167

168

RESULTS

169

170

Bone

171

172

Systematic description and comparison

173

174

Order Proboscidea Illiger, 1811

175

cf. Deinotherium Kaup, 1829 sp.

176

177

Material - humerus (sin.), partial diaphysis

178

179

Description

180

181

The specimen from Suomusjärvi is a fragment of the diaphysis (shaft) of a left humerus, belonging to a large-sized proboscidean (Fig. 2). It is fully re-mineralised and heavy for its size, with a mass of $3045 \mathrm{~g}$. The specimen is approximately from the middle of the shaft, preserving the narrowest part of the bone. Measurements of the specimen are shown in Table 1. Despite the fragmentary nature of the specimen, the middle part of the shaft is relatively well preserved in the caudal and lateral surfaces. The cranial surface is more eroded, especially in the proximal part of the specimen, but less so in the distal part which represents the narrowest part of the diaphysis. In the distal end of the specimen, the proximal-most edge of the crista 
supracondylaris lateralis is partly preserved. The proximal part of the specimen shows a slightly cracked and eroded proximal edge of crista humeri. The crista humeri overall is not prominent and the sulcus musculus brachialis is shallow, making the cross-section of the narrowest part of the shaft rounded rather than triangular in shape. This is likely to approximately represent the original morphology of the bone, because despite the slight fragmenting and erosion of the surface of the specimen, there does not appear to be major distortion to the middle of the shaft. Because the epiphyses are not preserved, it is impossible to estimate how fused they were, making it impossible to estimate the age or growth stage of the individual animal.

[Figure 2]

[Table 1]

\section{Comparison and discussion}

The lack of a prominent crista humeri and the subsequently shallow sulcus musculus brachialis, as well as the relatively rounded cross-section of the Suomusjärvi proboscidean humerus diaphysis, are features characteristic for the genus Deinotherium Kaup, 1829 (see Huttunen, 2004; Kovachev and Nikolov, 2006) (Figs 2-3). However, the fragmentary nature of the specimen raises some concern about the preservation of these features. In contrast to the Suomusjärvi specimen, gomphotheres (Gomphotheriidae) and mammutids (Mammutidae) typically exhibit strong crista humeri which sometimes result in an almost triangular rather than rounded cross-section of the middle of the humerus shaft (e.g. Göhlich, 2010; Tsoukala and Mol, 2014). Also the earlier, on average smaller-sized deinothere genus Prodeinotherium differs from Deinotherium in having a strong crista humeri and deep sulcus musculus brachialis (Huttunen, 2004). The reduced crista humeri of Deinotherium compared to other proboscidean taxa is visually shown in Fig. 4. In elephantimorphan proboscideans (Mammutidae, Gomphotheriidae and Elephantidae, sensu Shoshani and Tassy, 2005) the middle part of the 
humerus shaft tends to be relatively deep in relation to its width, although there is considerable

217 variation, whereas in deinotheres the mid-shaft is craniocaudally somewhat flattened. This is demonstrated by significantly higher average width/depth ratios in deinothere humeri than in the humeri of mammutids, gomphotheres and elephants (Fig. 5). In this respect also, the Suomusjärvi specimen is closer to the average of deinotheres than to the mammutids, gomphotheres and elephants (Fig. 5), although this characteristic does not definitely exclude the other taxa. We tentatively assign this specimen to cf. Deinotherium sp.

[Figure 3]

[Figure 4]

Measurements of the Suomusjärvi specimen fit with those reported for some specimens of Deinotherium, but are relatively small for that genus (Table 1). In particular, the Suomusjärvi specimen is close in size to the Deinotherium giganteum specimen from Munich described by Stromer (1938). Another example of a comparable medium-sized Deinotherium is the partial skeleton from the late Middle Miocene locality of Gratkorn, Austria, identified as Deinotherium levius or early D. giganteum, although this skeleton lacks humeri almost entirely (Aiglstorfer et al., 2014). Erosion of the Suomusjärvi specimen could have had some (but probably not major) effect on its measurements. It is also worth noting that because the epiphyses of the bone are lacking, we cannot estimate the age or growth stage of the individual, which makes it impossible to estimate whether it was a juvenile or a fully grown animal. This is particularly relevant in the case of proboscideans which continue to grow throughout their life. Other reported specimens of European Deinotherium, of presumably younger geological age, are notably larger in size and have variably been assigned to the species $D$. giganteum (e.g. Bachmayer and Zapfe, 1976; Huttunen, 2002; Christiansen, 2004), D. gigantissimum

242 (Stefanescu, 1894; Markov, 2008), D. thraceiensis (Kovachev and Nikolov, 2006), or D. 
proavum (e.g. Pickford and Pourabrishami, 2013).

\section{Sediment properties}

247 The mineral composition of the clayish fine fraction preserved in the bone differs from that of clay sediments in Finland, including the finding site. The sediment in the marrow cavity appears to originate from more alkaline bedrock compared to the Fennoscandian Shield region in which the bone was found. Such sediments are common further east, e.g. in today's Russia.

\section{Pollen content}

253

254

The pollen density in the sediment was extremely low, with only 147 palynomorphs counted from the entire residue remaining from ca. $1 \mathrm{~cm}^{3}$ of sediment. The condition of the palynomorphs was often (but not exclusively) poor, and only 98 palynomorphs could be identified, with 49 left unidentified as degraded and/or broken (37 grains), obscured (9) or unidentified (3). The identified palynomorphs (Table 2) are a combination of various PreQuaternary types, exotic to modern Europe, and types closely resembling modern and LateQuaternary North European pollen.

[Table 2]

The most commonly occurring palynomorph, at $26.5 \%$ abundance, is a large, tuberculate type of trilete spore (Fig. 6a-c). Well-preserved specimens of this type match excellently the description of the fossil species Pteridacidites variabilis Stuchlik \& Shatilova, 1996, with ca. 50-55 $\mu \mathrm{m}$ equatorial diameter, sides from polar view either straight or slightly convex but never concave, tuberculate exine with the tubercles on the proximal face concentrated around the laesura to form a ridge-like shape (Fig. 6a) while tubercles on the distal side coalesce to form 
sinuous shapes (Fig. 6c) (but never a reticulum as seen in some other Pteridacidites fossil species; Shatilova and Stuchlik, 1996), and the width of the equatorial collar 4-7 $\mu \mathrm{m}$ with the collar sometimes but not always narrowing at the angles (Shatilova and Stuchlik, 1996). Little variability is seen in size, shape or ornamentation between individual spores, and the examples shown in Fig. 6a-c are representative. Shatilova and Stuchlik (1996) regard Pteridacidites variabilis as the probable closest ancestor of the modern Pteris cretica L. (Cretan brake fern). The spores here designated as Pteridacidites variabilis also very closely resemble those of modern Pteris cretica (Reille, 1992; Shatilova and Stuchlik, 1996).

[Fig. 6]

280

The second-most commonly occurring type, at $15.3 \%$ abundance, is a small (equatorial diameter ca. 20-22 $\mu \mathrm{m}$ ), echinate trilete spore (Fig. 6d). These are comparable with the spores of modern Selaginella species (but not the much larger spores of $S$. selaginoides type which occur in late-Quaternary sediments of northern Europe). Consequently, they are here placed within Echinatisporis, a fossil genus used for Selaginella-type spores (e.g. Grímsson et al., 2011).

287

Monolete, bean-shaped spores resembling the modern Dryopteris-type occur at $12.2 \%$. In addition, the sample includes smaller numbers of other, large trilete spores of types not encountered in late-Quaternary sediments of northern Europe (an example in Fig. 6e).

A final clearly pre-Quaternary feature is the occurrence of pollen grains of Cupressaceae (but representing types other than Juniperus which also occurs in the North-European Quaternary). These are small (diameter 22-28 $\mu \mathrm{m}$ ) and round inaperturate grains, either fractured (Fig. 6f) or collapsed (Fig. 6g) in the thin-walled germination area. Numerous Cupressaceae tree species were elements in Palaeogene and Neogene forests of Europe, up to the Pliocene (Grímsson and 
Zetter, 2011). It is not possible to identify these specimens to genus level, as critical diagnostic features such as the papilla are not preserved or visible (Grímsson and Zetter, 2011).

The remaining palynomorphs (Table 2) represent types which occur in both Neogene and Quaternary sediments of Europe (Pinus, Poaceae, Betula, Artemisia, Chenopodiaceae, Alnus, Equisetum, and Juniperus).

\section{Diatom content}

The investigated sediment sample was abundant in diatoms. They were very well preserved and in good condition, and the diatom assemblage was uniform suggesting a consistent sedimentation environment. This indicates that the analyzed sediment sample is not redeposited. The results of the diatom analysis are presented in Table 3 and micrographs of the most commonly occurring types in Fig. 7. The diatom assemblage was unilateral, i.e. a few diatom species dominate the flora. The most common diatom species were the (mero)planktonic Alveolophora sp. and Aulacoseira granulata (Ehrenberg) Simonsen (1979), covering about 90 $\%$ of the total diatom sum. Other species identified at species level were the planktonic species Cyclotella stelligera Cleve \& Grunow, and the benthic species Cocconeis pediculus Ehrenberg and Nitschia amphibia Grunow. Exluding Alveolophora sp., the other identified species are still common today in freshwater environments and favour alkaline waters. For example, Aulacoseira granulata is a freshwater, meroplanktonic species which prefers alkaline, eutrophic waters. The species is found also in Miocene deposits and remains common today.

[Table 3]

[Figure 7]

The Alveolophora genus is currently understood to be entirely extinct as it existed only from the 
Late Eocene until the end of the Miocene (Kozyrenko et al., 2008). One finding of Alveolophora species is dated to the Early Pliocene (Kozyrenko et al., 2008). Alveolophora is primarily reported from fossil localities in Asia, including the Russian Far East (Khursevich, 1994; Kozyrenko et al., 2008) and Lake Baikal (Khursevich and Fedenya, 2006). Recently, three new species of this extinct diatom genus have been described from Miocene sediments in western North America (Usoltseva et al., 2013). Previous studies indicate that all found species of Alveolophora are freshwater ones and that the distributions of the species belonging to this genus are regional rather than global. The Alveolophora sp. found in our sediment sample could not be identified to species level suggesting that it is a new, previously unknown species of this extinct genus.

\section{DISCUSSION}

\section{Chronological constraints}

The most common diatom species Alveolophora sp. of the sediment existed from the late Eocene to the late Miocene, between ca. 32 and $5 \mathrm{Ma}$. As the genus became extinct at the end of the Miocene, this limits the minimum age of the bone at about 5 Ma. The pollen and spore content appears to rule out the pre-Miocene, as fossil spores bearing similarities to Pteris are only documented in the European fossil record starting in the Miocene (Shatilova and Stuchlik, 1996). However, this inference is uncertain as few Palaeogene and Neogene deposits survive in northernmost Europe, and thus the data on the regional vegetation is scarce.

However, a more robust estimate of the maximum age can be done based on the expansion of proboscids from Africa. Proboscideans only arrived in Europe in the Early Miocene, ca. 19-17 Ma ago (Göhlich, 1999). The genus Deinotherium arrived in Europe in the Middle Miocene, somewhere between 16 and $13 \mathrm{Ma}$, and became extinct in the Pliocene, somewhere between 5 
and $2 \mathrm{Ma}$ (Göhlich, 1999; see also the NOW database: Fortelius, 2015). The probable affinity of

352 the Suomusjärvi specimen with this genus, together with the information from the diatoms and

353 pollen, would place the age of the find within this time frame, probably in the Late Miocene (ca.

354 11-5 Ma). However, the comparably small size of the specimen for the genus Deinotherium

355 could even point at a late Middle Miocene (ca. 16-11 Ma) age, because the size is close to the

356 late Middle Miocene specimens of Deinotherium from Austria and Germany, and there was a progressive size increase in European Deinotherium through time (see Aiglstorfer et al., 2014). This is, however, highly speculative, especially because the age or growth stage of the individual animal cannot be reliably estimated. Furthermore, the nutritional and general health status of the individual cannot be assessed.

361

In summary, a Quaternary age can be conclusively rejected based on the presence of numerous unequivocally pre-Quaternary pollen, spore and diatom types. Further constraints are provided by the presence of the diatom Alveolophora sp. which suggests a minimum age of $5 \mathrm{Ma}$, while a maximum age of $19 \mathrm{Ma}$ is derived from the earliest appearance of proboscideans outside Africa. There is nothing in the pollen, spores, or diatoms to contradict this age bracket of 19-5 Ma.

\section{Palaeobiogeographic significance of the Suomusjärvi proboscidean specimen}

The proboscidean humerus specimen from Suomusjärvi, Finland, latitude $60^{\circ} 22^{\prime} \mathrm{N}$, is the northernmost Miocene proboscidean fossil found anywhere in the world so far. Even accounting for all the possible transport directions of the specimen, it could not have been drifted from very much further south, and indeed it is more likely to originate from even further north than where it was found (see the discussion below). In Eurasia, the previously northernmost proboscidean finds come from localities up to ca. $52^{\circ} \mathrm{N}$ (e.g. Ermak and Bestobe, Kazakhstan, and Rothenstein, Germany), and the northernmost finds of Deinotherium from Germany $\left(49-50^{\circ} \mathrm{N}\right)$, e.g from N-Ebing Inn, Wissberg and Gau-Weinheim (NOW database: Fortelius, 2015). In North 
378 America the northernmost finds of the Miocene proboscideans Zygolophodon and 379 Gomphotherium come from Wood Mountain, Saskatchewan, Canada, 49 $37^{\prime} \mathrm{N}$ (Madden and 380 Storer, 1985). The ca. $50^{\circ} \mathrm{N}$ northern limit in the distribution of Miocene proboscidean finds has 381 most likely been a bias caused by a lack of mammal bearing fossil localities further north, and 382 there is no ecological or climatic reason to expect that proboscideans could not have occurred further north. In fact, the Miocene palaeobotanic records from Denmark and Iceland show a mixture of temperate and subtropical vegetation indicating subtropical climate in Northern Europe, substantially warmer than at present (Larsson et al., 2006; Grímsson et al., 2007), which is supported by the pollen and diatoms associated with the Suomusjärvi specimen (see discussion below). Humid, heavily wooded conditions prevailed throughout the Late Miocene in the proboscidean localities from Germany (Franzen et al., 2003; Costeur et al., 2013), although the habitats of Deinotherium further north could have been different. Most likely representing the genus Deinotherium, the Suomusjärvi proboscidean would have been a large woodland browser feeding primarily on leaves from trees (see e.g. Calandra et al., 2008). This would fit well with the suggested environmental interpretations.

\section{Interpretation based on the microfossil content and environmental reconstruction}

A remarkable feature of the palynoflora is that $54 \%$ of the count consists of spores of just three types (Pteridacidities variabilis, Echinatisporis sp., and Dryopteris-type), presumably representing pteridophyte species of Pteris, Selaginella, and the various pteridophyte taxa producing monolete spores commonly lumped together as the Dryopteris-type (e.g. Moore et al., 1991). In the Neogene, all three genera (Pteris, Selaginella, Dryopteris) are regarded to have occurred as components in the shoreline vegetation of lakes or streams (Shatilova and Stuchlik, 1996; Grímsson et al., 2011). As these spores occur at anomalous frequencies compared with other European Miocene deposits (Fig. 8), in which pteridophyte spores occur only at very low numbers (e.g. Jiménez-Moreno et al., 2005; Larsson et al., 2006; Grímsson et al., 2011), and as 
405

just a few spore types dominate the palynoflora, the likeliest explanation is that the bone was first deposited very close to the shore of a lake or a stream. This caused the observed overrepresentation of the shoreline pteridophytes which happened to occur at the site of deposition, while comparatively few pollen from the regional terrestrial vegetation are seen.

\section{[Figure 8]}

Although all the pollen and spore types found do occur in the European Miocene, we consider it probable that some Quaternary admixture has taken place during the later transport of the bone. Admixture of Quaternary pollen is suggested especially by the relatively large proportions of Chenopodiaceae and Artemisia (Table 1). These taxa are key components in the tundra-steppe vegetation of the cold stages of the Quaternary, while in the European Miocene palynoflora, although present, they do not typically occur at such percentages (e.g. Stuchlik and Shatilova, 1987; Jiménez-Moreno et al., 2005; Larsson et al., 2006). We note that while the unequivocally pre-Quaternary spore and pollen types were generally in good condition (see examples in Fig. 6), the pollen and spore types consistent with a Quaternary age were often much worse preserved, being superficially similar to the reworked pollen commonly seen in Quaternary glacial sediments of Fennoscandia. The observed palynoflora might best be explained as a Neogene local shoreline assemblage (with some Cupressaceae from the surrounding terrestrial vegetation included) later mixed with a smaller fraction of reworked late-Quaternary pollen (Alnus, Betula, Juniperus, Pinus, Artemisia, Chenopodiaceae, Poaceae, Equisetum) during the transport of the bone.

Pteris cretica today has a wide distribution in subtropical and tropical climates, including the Mediterranean and Black Sea regions, Madagascar, South and East Asia, Central America and the Caribbean, and Florida (Shatilova and Stuchlik, 1996). The presence of its probable close ancestor Pteridacidites variabilis thus suggests at least a subtropical climate at the time of bone 
deposition. We note that other Pteris species also have a mainly subtropical and tropical 433 distributions (Shatilova and Stuchlik, 1996), while the Pteris species constituting the Pteris cretica complex in North America occur in the tropics (Martínez and Morbelli, 2009), and thus the inference of at least subtropical conditions is likely robust to the species-level identification of our Pteris-type spores. Results on Miocene vegetation in Austria (Grímsson and Zetter, 2011; Grímsson et al., 2011), Germany (Uhl et al., 2006), Denmark (Larsson et al., 2006), and Iceland (Grímsson et al., 2007), showing a mixture of temperate and subtropical vegetation elements and a generally subtropical climate, preclude full-tropical conditions in northern Europe, and thus the final climatic inference becomes subtropical.

Diatoms indicate freshwater, alkaline and eutrophic sedimentation environment, i.e. the bone was stratified in a river or small lake of relatively high nutrient content. This sedimentation environment might indicate a relatively warm climate. Thus the diatom results are consistent with the pollen-based inference both in terms of depositional environment and climate.

Miocene proboscidean assemblages from Europe are typically associated with sediments indicating riparian environments or the presence of substantial waterbodies. This probably indicates a preference of these animals to seek waterbodies in order to get a regular access to drinking water and to wallow in water, similarly to modern elephants. Major Early and Middle Miocene proboscidean localities, such as German Molasse Basin localities and Sansan from France, indicate the presence of riparian, lacustrine and wetland environments (Calandra et al., 2010; Costeur et al., 2012). The early Late Miocene (Vallesian) locality of Eppelsheim in Germany, the type locality of the abundant and wide-spread European Late Miocene deinothere species Deinotherium giganteum, consists of fluvial deposits of the Dinotheriensande Formation deposited by the ancient Rhine River (Franzen et al., 2003). The same locality has yielded remains of the gomphotheriid proboscidean Tetralophodon longirostris. Pollen records from Eppelsheim indicate a floodplain environment surrounded by subtropical forests (Franzen et al., 
460 Germany has provided fossils of Deinotherium and gomphotheres (Franzen et al., 2013). The environment of Dorn-Dürkheim 1 was suggested by Costeur et al. (2013) to have comprised both forest and patches of open vegetation based on the diverse mammal community. Moreover, e.g. the abundant and diverse record of fossil beavers suggests the presence of substantial waterbodies and river channels in the palaeoenvironment of Dorn-Dürkheim 1 (Costeur et al., 2013). The inferred riparian environment of the Suomusjärvi proboscidean are consistent with these observations.

\section{Constraints on transport direction}

The discovery of an apparently Miocene-age bone from the southern Finland presents a considerable conundrum, as no Miocene bones are known from the Nordic countries. To date, the northernmost findings are from ca. $50^{\circ} \mathrm{N}$ (Fig. 8). As even deposits of Miocene age are not known from either southern Finland or the near vicinity (Rasmussen et al., 2008), the implication is that the bone must have been transported over considerable distance to the site of discovery.

One possibility for bone origin is glacial transport from the North, during one or more of the latest Quaternary glaciations. The site of discovery lies south of the Fennoscandian ice divide, and in the general direction of glacial erratic drift from the ice divide (e.g. Donner, 1989). As noted, sparse terrestrial Miocene sediments have been discovered in the northern Finland icedivide region (Hirvas and Tynni, 1976; Tynni, 1982), presenting a possible source region. However, as the bone was found in clay representing an early-Holocene stage of the Baltic Sea (Yoldia Sea), the final transport and deposition must have been through iceberg rafting. Given the prevailing currents in the Baltic Sea, this transport phase likely had a westward direction. However, considering the great distance to closest known Miocene deposits (Fig. 8), this early- 
Holocene iceberg rafting was likely preceded by other transport phases, including one or more

487 phases of glacial and/or glacio-fluvial transport during the late Quaternary. Considering the

488 likelihood of multiple phases and modes of transport, but with the exact number of transport phases and modes unknown, we are unable to estimate the likely region of origin with any confidence.

We note, however, that both the alkaline composition of the bone-cavity sediment and the diatom flora suggest an origin in a region of alkaline bedrock. This points towards an origin in the east, in the Russian Plain region, instead of the acidic bedrock region of the Fennoscandian Shield. The maximum transport distance is set by the maximum extent of Quaternary glaciations in northern Europe (e.g. Svendsen et al., 2004), as all credible transport mechanisms require the presence of an ice sheet. Together, these considerations suggest a possible origin in the northern part of European Russia.

The pollen, spores and diatoms found within the bone include some environmental indicators, but we are unable to better pinpoint the origin of the bone with these, especially as only sparse Miocene sediments survive in northern Europe to serve as points of comparison and Miocene environments and species compositions in northern Europe are thus poorly resolved. As noted, the presence of Pteridacidites variabilis suggests a subtropical climate during bone deposition.

505 Climate reconstructions from other European sites suggest humid-subtropical-type climates ( 506 Köppen classification Cfa) to have prevailed widely in central and northern Europe, from 507 Austria to Iceland (Uhl et al., 2006; Grímsson et al., 2007, 2011; Grímsson and Zetter, 2011) during the Miocene, with further indications of subtropical trees such as palms and Engelhardia also thriving in Denmark (Larson et al., 2006). Taken together, these evidence suggests a weak latitudinal temperature gradient in Europe. Thus, while the pollen and spore content in the Suomusjärvi bone are consistent with these palaeoclimatic reconstructions from other central and northern European sites, the bone cannot confidently be said to originate from any specific 
region.

514

515 The diatoms within the bone's marrow cavity do not support transport from northern Finland as

516 this kind of diatom assemblage has not been previously discovered from Finland. Of course, this

517 can be due to the very sparse Miocene deposits found in Finland and thus the transport from the north cannot be ruled out. Sediment properties and the presence of Alveolophora sp. might suggest transport from the east (Russia) as there this species is rather common in the Miocene sediments, although most of the findings originate as far away as the Russian Far East. However, the lack of Alveolophora findings from the W-NW European Russia can be due to the regionally restricted occurrence of the species of this diatom genus and/or the several glaciations which have eroded the area.

524

\section{CONCLUSIONS}

527 We return here to the four questions presented in the Introduction:

1. The specimen from Suomusjärvi was identified as a partial diaphysis of the left humerus of a large proboscidean. Based on a few key morphological features and size of the specimen, it most likely represents the genus Deinotherium, and it is described here as cf. Deinotherium sp. Coming from the latitude of ca. $60^{\circ} \mathrm{N}$, and possibly originating from even further north, this is the northernmost Miocene proboscidean fossil found anywhere in the world. The previously northernmost finds, including those of European Deinotherium, come from localities ca. $50^{\circ} \mathrm{N}$.

2. A minimum age of $5 \mathrm{Ma}$ for the bone is set based on the presence of an unidentified diatom species belonging to the genus Alveolophora, while a maximum age of $19 \mathrm{Ma}$ is set by the earliest arrival of proboscideans to Europe. Together, these evidence confirm a Miocene age for the specimen. If the identification of the bone as Deinotherium sp. is 
correct, the maximum age is further reduced to $13.5 \mathrm{Ma}$ based on the first appearance of this genus in Europe.

3. The pollen and diatom assemblages suggest that the bone was deposited close to the

JSS acknowledges funding from the Academy of Finland program on long-term environmental changes (project no. 278692) and the Finnish Cultural Foundation. JS was working at the Natural History Museum of London during this collaboration, funded by Osk. Huttunen Foundation, Finland. MU acknowledges funding from the project no. VI.50.1.3 (0345-20140001). The Suomusjärvi bone has been donated to and is on permanent display at the Finnish Museum of Natural History in Helsinki, Finland. The Elephas recki humerus from Olduvai shown in Fig. 3 is stored in the Natural History Museum, London, UK. The Mammuthus primigenius humerus from Lampertheim, Germany, shown in Fig. 4 is stored in the Staatliches Museum für Naturkunde, Stuttgart. We thank Reinhard Ziegler from Staatliches Museum für Naturkunde, Stuttgart, for granting a permission to use the photo of a mammoth humerus in Fig. 4e, and Spyridoula Pappa from the Natural History Museum of London for the permission to 
use the photo of Elephas recki humerus in Fig. 3.

568

569

\section{REFERENCES}

570

571

Aiglstorfer, M., Göhlich, U.B., Böhme, M., Gross, M., 2014. A partial skeleton of Deinotherium

572

(Proboscidea, Mammalia) from the late Middle Miocene Gratkorn locality (Austria).

573

Palaeobiodiversity and Palaeoenvironments 94, 49-70.

574

575

Bachmayer, F., Zapfe, H., 1976. Ein bedeutender Fund von Dinotherium aus dem Pannon von

576

Niederösterreich. Annalen des Naturhistorischen Museums in Wien 80, 145-162.

577

578

Battarbee, R.W., 1986. Diatom analysis. In Berglund, B.E. (ed.): Handbook of Holocene

579

Palaeoecology and Palaeohydrology. John Wiley \& Sons, Chichester, 527-570.

580

581

582

Björck, S., 1995. A review of the history of the Baltic Sea, 13.0-8.0 ka BP. Quaternary International 27, 19-40.

583

584

Bravo-Cuevas, V.M., Morales-García, N.M., Cabral-Perdomo, M.A., 2015. Description of 585

mastodons (Mammut americanum) from the late Pleistocene of southeastern Hidalgo, central

Mexico. Boletín de la Sociedad Geológica Mexicana 67, 337-347.

587

588

Calandra, I., Göhlich, U.B., Merceron, G., 2008. How could sympatric megaherbivores coexist?

589 Example of niche partitioning within a proboscidean community from the Miocene of Europe.

590 Naturwissenschaften 95, 831-838.

591

592 Calandra, I., Göhlich, U.B., Merceron, G., 2010. Feeding preferences of Gomphotherium 593 subtapiroideum (Proboscidea, Mammalia) from the Miocene of Sandelzhausen (Northern 
594 Alpine Foreland Basin, southern Germany) through life and geological time: evidence from 595 dental microwear analysis. Paläontologische Zeitschrift 84, 205-215.

596

597 Christiansen, P., 2004. Body size in proboscideans, with notes on elephant metabolism. 598 Zoological Journal of the Linnean Society 140, 523-549.

599

600 Costeur, L., Legendre, S., 2008. Mammalian communities document a latitudinal environmental 601 gradient during the Miocene Climatic optimum in Western Europe. PALAIOS 23, 280-288.

602

603 Costeur, L., Guérin, C., Maridet, O., 2012. Paléoécologie et paléoenvironnement du site 604 Miocène de Sansan. In: Peigné, S., Sen, S. (eds), Mammifères de Sansan. Muséum National 605 d'Histoire Naturelle, Paris, 661-669.

606

607 Costeur, L., Maridet, O., Montuire, S., Legendre, S., 2013. Evidence of northern Turolian 608 savanna-woodland from the Dorn-Dürkheim 1 fauna (Germany). Palaeobiodiversity and Palaeoenvironments 93, 259-275.

610

611 Donner, J., 1989. Transport distances of Finnish crystalline erratics during the Weichselian 612 glaciation. Geological Survey of Finland, Special Paper 7, 7-13.

613

614 Ferretti, M.P., 2010. Anatomy of Haplomastodon chimborazi (Mammalia, Proboscidea) from 615 the late Pleistocene of Ecuador and its bearing on the phylogeny and systematics of South 616 American gomphotheres. Geodiversitas 32, 663-721.

617

618 Fortelius, M. (coordinator), 2015. New and Old Worlds Database of Fossil Mammals (NOW). 619 University of Helsinki. http://www.helsinki.fi/science/now/. 
621 Franzen, J.L., Fejfar, O., Storch, G., Wilde, V., 2003. Eppelsheim 2000 - new discoveries at a 622 classic locality. In: Reumer, J.W.F. \& Wessels, W. (eds.) Distribution and Migration of Tertiary 623 Mammals in Eurasia. A Volume in Honour of Hans De Brujn - Deinsea 10, 217-234.

624

625 Franzen, J.L., Pickford, M., Costeur, L., 2013. Palaeobiodiversity, palaeoecology, 626 palaeobiogeography and biochronology of Dorn-Dürkheim 1 - a summary. Palaeobiodiversity and Palaeoenvironments 93, 277-284.

628

629 Grímsson, F., Zetter, R., 2011. Combined LM and SEM study of the Middle Miocene 630 (Sarmatian) palynoflora from the Lavanttal Basin, Austria: Part II. Pinophyta (Cupressaceae, 631 Pinaceae and Sciadopityaceae). Grana 50, 262-310.

632

Grímsson, F., Denk, T., Simonarson, L.A., 2007. Middle Miocene floras of Iceland - the early colonization of an island? Review of Palaeobotany and Palynology 144, 181-219.

635

Grímsson, F., Zetter, R., Baal, C., 2011. Combined LM and SEM study of the Middle Miocene 637 (Sarmatian) palynoflora from the Lavanttal Basin, Austria: Part I. Bryophyta, Lycopodiophyta, 638 Pteridophyta, Ginkgophyta, and Gnetophyta. Grana 50, 102-128.

639

640 Göhlich, U.B., 1998. Elephantoidea (Proboscidea, Mammalia) aus dem Mittel- und Obermiozän 641 der Oberen Süßwassermolasse Süddeutschlands: Odontologie und Osteologie. Münchner 642 Geowissenschaftliche Abhandlungen A 36, 1-245.

643

644 Göhlich, U.B., 1999. Order Proboscidea. In: Rössner G, Heissig K (eds) The Miocene land 645 mammals of Europe. Verlag Dr. Friedrich Pfeil, München, 157-168.

647 Göhlich, U.B., 2010. The Proboscidea (Mammalia) from the Miocene of Sandelzhausen 
650 Hirvas, H., Tynni, R., 1976. Tertiary clay deposits at Savukoski, Finnish Lapland, and 651 observations of Tertiary microfossils, preliminary report (in Finnish with an English summary). 652 Geologi 28, 33-40.

653

654 Huttunen, K., 2002. Systematics and taxonomy of the European Deinotheriidae (Proboscidea, 655 Mammalia). Annalen des Naturhistorischen Museums in Wien A 103, 237-250.

656

657

Huttunen, K., 2004. On a Prodeinotherium bavaricum (Proboscidea, Mammalia) skeleton from 658 Franzensbad, Czech Republic. Annalen des Naturhistorischen Museums in Wien A 105, 333659 361.

660

Huttunen, K., Göhlich, U.B., 2002. A partial skeleton of Prodeinotherium bavaricum 662 (Proboscidea, Mammalia) from the Middle Miocene of Unterzolling (Upper Freshwater Molasse, Germany). Geobios 35, 489-514.

664

665

Jiménez-Moreno, G., Rodríguez-Tovar, F.J., Pardo-Igúzquiza, E., Fauquette, S., Suc, J.-P., 666 Müller, P., 2005. High-resolution palynological analysis in late early-middle Miocene core from the Pannonian Basin, Hungary: climatic changes, astronomical forcing and eustatic fluctuations in the Central Paratethys. Palaeogeography, Palaeoclimatology, Palaeoecology 216, $73-97$.

670

671 Kaiser, T.M., 2004. The dietary regimes of two contemporaneous populations of Hippotherium 672 primigenium (Perissodactyla, Equidae) from the Vallesian (Upper Miocene) of Southern 673 Germany. Palaeogeography, Palaeoclimatology, Palaeoecology 198, 381-402. 
677 Khursevich, G.K. 1994. Morphology and taxonomy of some centric diatom species from the

678 Miocene sediments of the Dzhilinda and Tunkin hollows. In: Proceedings of the 11th

679 International Diatom Symposium (Ed. by J.P. Kociolek), pp. 269-280. California

680 Academy of Sciences, San Francisco.

681

682 Khursevich, G.K., Fedenya, S.A. 2006. Morphology of new fossil species of Concentrodiscus 683 and Alveolophora (Bacillariophyta) from bottom sediment of Lake Baikal. International Journal 684 on Algae 8, 78-90.

685

Kovachev, D., Nikolov, I., 2006. Deinotherium thraceiensis sp. nov. from the Miocene near Ezerovo, Plovdiv District. Geologica Balcanica 35, 5-40.

Kozyrenko, T.F., Strelnikova, N.I., Khursevich, G.K., Tsoy I.B., Yakovschikova, T.K., 690 Mukhina, V.V., Olshtynskaja, A.P., Semina, G.I., 2008. The diatoms of Russia and adjacent 691 countries. Fossil and recent. II, 5 (Ed. by N.I. Strelnikova \& I.B. Tsoy). St. Petersburg 692 University Press, St. Petersburg, Russia. 171 pp. [In Russian.]

693

Krammer, K., Lange-Bertalot, H., 1986-1991. Bacillariophyceae. Teil 1-4. Süsswasserflora von Mitteleuropa 2/1, 876 pp. (1: Naviculaceae, 1986), 2/2, 596 pp. (2: Bacillariaceae, Epithemiaceae, Surirellaceae, 1988), 2/3, 576 pp. (3: Centrales, Fragilariaceae, Eunotiaceae, 697 1991a), 2/4, 437 pp. (4: Achnanthaceae \& Kritische Ergänzungen zu Navicula (Lineolatae und Gomphonema, 1991b). Gustav Fischer Verlag, Stuttgart-New York.

699

700 Larsson, L.M., Vajda, V., Rasmussen, E.S., 2006. Early Miocene pollen and spores from western Jylland, Denmark - environmental and climatic implications. GFF 128, 261-272. 
703 Madden, C.T., Storer, J.E., 1985. The Proboscidea from the Middle Miocene Wood Mountain 704 Formation, Saskatchewan. Canadian Journal of Earth Sciences 22, 1345-1350.

705

706

Markov, G.N., 2008. The Turolian proboscideans (Mammalia) of Europe:

707

preliminary observations. Historia Naturalis Bulgarica 19, 153-178.

708

709

Martínez, O.G., Morbelli, M.A., 2009. The spores of Pteris cretica complex (Pteridaceae-

710

Pteridophyta) in America. Grana 48, 193-204.

711

712

Mölder, K., Tynni, R. 1967-1973. Über Finnlands rezente und subfossile Diatomeen. I-VI.

Comptes Rendus de la Societé géologique de Finlande No. XXXIX, 199-217 (1967), Bulletin

of the Geological Society of Finland 40, 151-170 (1968), Bulletin 41, 235-251 (1969), Bulletin 42, 129-144 (1970), Bulletin 43, 203-220 (1971), Bulletin 44, 141-149 (1972), Bulletin 45, 159-179 (1973).

717

Moore, P.D., Webb, J.A., Collinson, M.E., 1991. Pollen Analysis. Blackwell, Oxford.

719

720

Pickford, M., Pourabrishami, Z., 2013. Deciphering Dinotheriensande deinotheriid diversity.

Palaeobiodiversity and Palaeoenvironments 93, 121-150.

722

723

Rasmussen, E.S., Heilmann-Clausen, C., Waagstein, R., Eidvin, T., 2008. The Tertiary of

Norden. Episodes 31(1), 1-7.

Reille, M., 1992. Pollen et spores d'Europe et d'Afrique du Nord. URA CNRS, Marseille. 
Ross, R., Cox, E.J., Karayeva, N.I., Mann, D.G., Paddock, T.B.B., Simonsen, R., Sims, P.A., 1979. An amended terminology for the siliceous components of the diatom cell. Nova Hedwigia Beiheft 64, 513-533.

Saarnisto, M., Saarinen, T., 2001. Deglaciation chronology of the Scandinavian Ice Sheet from the Lake Onega Basin to the Salpausselkä End Moraines. Global and Planetary Change 31. $387-405$.

Shatilova, I.I., Stuchlik, L., 1996. The genus Pteris L. in the Neogene deposits of western Georgia. Acta Palaeobotanica 36, 5-77.

Shoshani, J., Tassy, P., 2005. Advances in proboscidean taxonomy \& classification, anatomy \& physiology, and ecology \& behavior. Quaternary International 126-128, 5-20.

Stefanescu, G., 1894. Dinotherium gigantissimum. Annuarulu Museului de Geologia si de Paleontologia 1894, 126-199.

Stromer, E., 1938. Huftier-Reste aus dem unterstpliocänen Flinzsande Münchens. Abhandlungen der Bayerischen Akademie der Wissenschaften, MathematischNaturwissenschaftliche Abteilung 44, 1-39.

Stuchlik, L., Shatilova, I.I., 1987. Palynological study of Neogene deposits of southern Poland and western Georgia. Acta Palaeobotanica 27(2), 21-52.

Svendsen, J.I., Alexanderson, H., Astakhov, V.I., Demidov, I., Dowdeswell, J.A., Funder, S., Gataullin, V., Henriksen, M., Hjort, C., Houmark-Nielsen, M., Hubberten, H.W., Ingólfsson, Ó., Jakobsson, M., Kjær, K.H., Larsen, E., Lokrantz, H., Lunkka, J.P., Lyså, A., Mangerud, J., 
Matiouchkov, A., Murray, A., Möller, P., Niessen, F., Nikolskaya, O., Polyak, L., Saarnisto, M., Siegert, C., Siefert, M.J., Spielhagen, R.F., Stein, R., 2004. Late Quaternary ice sheet history of northern Eurasia. Quaternary Science Reviews 23, 1229-1271.

Tsoukala, E., Mol, D., 2014. The Proboscidea of the Early Villafranchian site of Milia (Grevena, Macedonia, Greece). Quaternary International xxx, $1-21$, doi:10.1016/j.quaint.2014.10.026.

Tynni, R., 1975-1980. Über Finnlands rezente und subfossile Diatomeen. Bulletin of the Geological Society of Finland 274, 1-55 (1975), Bulletin 284, 1-37 (1976), Bulletin 296, 1-55 (1978), Bulletin 312, 1-93 (1980).

Tynni, R., 1982. The reflection of geological evolution in Tertiary and interglacial diatoms and silicoflagellates in Finnish Lapland. Geological Survey of Finland, Bulletin 320, 40 pp.

Uhl, D., Bruch, A.A., Traiser, C., Klotz, D., 2006. Palaeoclimate estimates for the Middle Miocene Schrotzburg flora (S Germany): a multi-method approach. International Journal of Earth Sciences 95, 1071-1085.

Ukkonen, P., 2001. Shaped by the Ice Age: Reconstructing the history of mammals in Finland during the Late Pleistocene and the Early Holocene. Yliopistopaino, Helsinki, 41 pp.

Ukkonen, P., Miettinen, A., Hanski, I.K., 2010. Mammoth ulna found in Eemian sediments in Helsinki, Finland (in Finnish with an English summary). Geologi 62, 23-29.

Ukkonen, P., Aaris-Sørensen, K., Arppe, L., Clark, P.U., Daugnora, L., Lister, A.M., Lõugas, L., Seppä, H., Sommer, R.S., Stuart, A.J., Wojtal, P., Zupiņš, I., 2011. Woolly mammoth 
782

783

784

785

786

787

788

789

790

791

792

793

794

795

796

797

798

799

800

801

802

803

804

805

806

807

808

(Mammuthus primigenius Blum.) and its environment in northern Europe during the last glaciation. Quaternary Science Reviews 30, 693-712.

Usoltseva, M., Kociolek, J.P., Khursevich, G.K., 2013. Three new species of Alveolophora (Aulacoseiraceae, Bacillariophyceae) from Miocene deposits in western North America. Phycologia 52, 109-117.

Wang, F., Chen, N., Zhang, Y., Yang, H., 1997. Pollen Flora of China. Science Press, Beijing, $461 \mathrm{pp}$.

(1)

.

(1)


809 Table 1. Measurements of the Suomusjärvi specimen and some European deinothere humerus 810 specimens. Min. diaph. width = smallest latero-medial diameter of diaphysis. Min. diaph. depth $811=$ smallest cranio-caudal diameter of diaphysis. Min. diaph circ. $=$ smallest circumference of 812 diaphysis.

813

\begin{tabular}{|c|c|c|c|c|c|}
\hline $\begin{array}{ll}\text { Measurement } & \text { cf. Deinotherium } \\
(\mathrm{mm}) & \text { sp., Suomusjärvi }\end{array}$ & $\begin{array}{l}\text { Deinotherium } \\
\text { giganteum, } \\
\text { Munich } \\
\text { (Stromer, 1938) }\end{array}$ & $\begin{array}{l}\text { Deinotherium } \\
\text { giganteum, } \\
\text { Kettlasbrunn } \\
\text { (measurements } \\
\text { by J. Saarinen) }\end{array}$ & $\begin{array}{l}\text { Deinotherium } \\
\text { thraceiensis, } \\
\text { Ezerovo } \\
\text { (Kovachev and } \\
\text { Nikolov, 2006) }\end{array}$ & $\begin{array}{l}\text { Prodeinotherium } \\
\text { bavaricum, } \\
\text { Franzenbad } \\
\text { (Huttunen, 2004, } \\
\text { J. Saarinen) }\end{array}$ & $\begin{array}{l}\text { Prodeinotherium } \\
\text { bavaricum, } \\
\text { Unterzolling } \\
\text { (Huttunen and } \\
\text { Göhlich, 2002) }\end{array}$ \\
\hline Min. diaph. width 114 & 115 & 170 & 190 sin., 195 dext. & 104 & 132 \\
\hline Min. diaph. depth 99 & - & 154 & - & 95 & - \\
\hline Min. diaph. circ. 359 & - & 545 & - & 350 & 420 \\
\hline
\end{tabular}


832 Table 2. Pollen analysis results.

833

834

835

836

837

838

839

840

841

\begin{tabular}{|lll|}
\hline Type & Count & \% of total \\
\hline Pteridacidites variabilis & 26 & 26.5 \\
\hline Echinatisporis sp. & 15 & 15.3 \\
\hline Dryopteris-type & 12 & 12.2 \\
\hline Pinus & 12 & 12.2 \\
\hline Poaceae & 10 & 10.2 \\
\hline Betula & 6 & 6.1 \\
\hline Indet. trilete spores & 6 & 6.1 \\
\hline Artemisia & 3 & 3.1 \\
\hline Chenopodiaceae & 3 & 3.1 \\
\hline Indet. Cupressaceae (Neogene non-Juniperus types) & 2 & 2.0 \\
\hline Alnus & 1 & 1.0 \\
\hline Equisetum & 1 & 1.0 \\
\hline Juniperus & 1 & 1.0 \\
\hline Total count & 98 & 100.0 \\
\hline & &
\end{tabular}

842

843

844

845

846

847

848

849

850

851

852

853

854

855

856

857

858 
Table 3. Diatom analysis results.

860

\begin{tabular}{|lll|}
\hline Diatom species & Count & \% of total \\
\hline Alveolophora sp & 65.5 & 54.6 \\
\hline Aulacoseira granulata & 42.5 & 35.4 \\
\hline Cocconeis pediculus & 3 & 2.5 \\
\hline Cyclotella stelligera & 2 & 1.7 \\
\hline Gomphonema sp. & 2 & 1.7 \\
\hline Nit2schia amphibia & 2 & 1.7 \\
\hline Nit₹schia sp1 & 2 & 1.7 \\
\hline Nitzschia sp2 & 1 & 0.8 \\
\hline Total count & $\mathbf{1 2 0}$ & $\mathbf{1 0 0}$ \\
\hline
\end{tabular}

861

862

863

864

865

866

867

868

869

870

871

872

873

874

875

876

877

878

879

880 

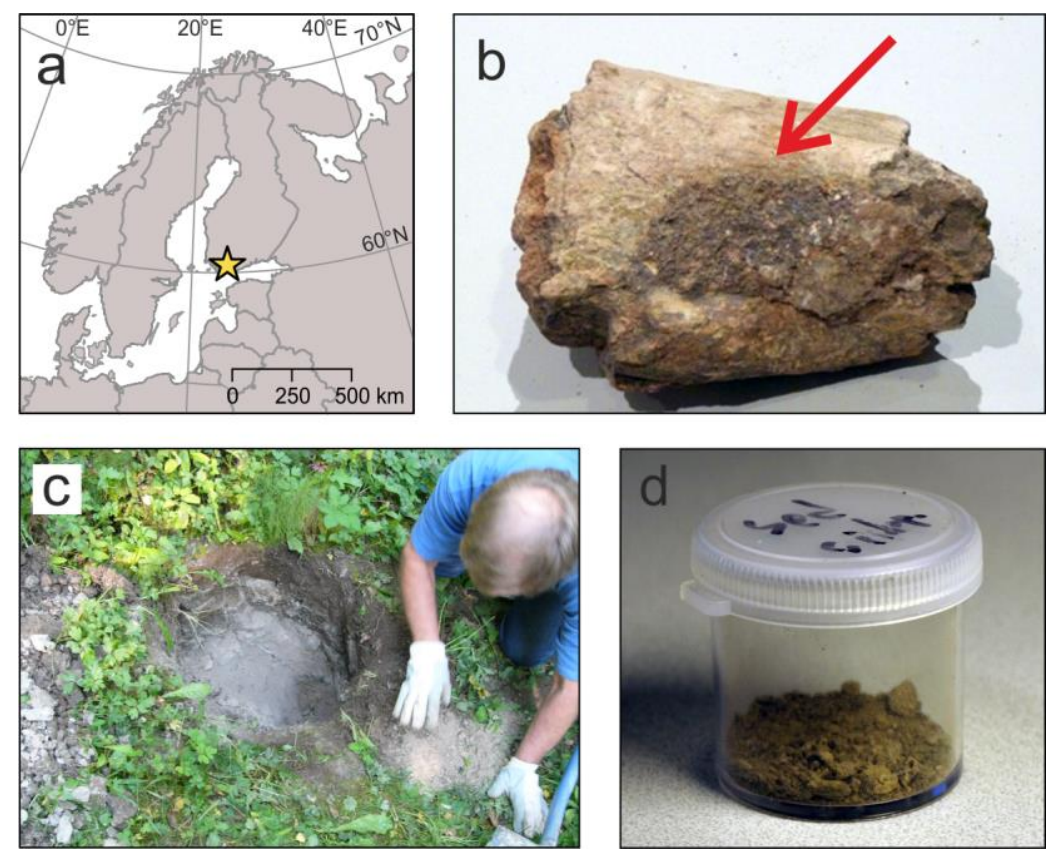

882

883 Figure 1. (a) Site of bone discovery. (b) Photograph of the bone (the brownish sediment

884 indicated with a red arrow) (Photo: Laura Hiisivuori, the Finnish Museum of Natural History). (c) An excavation in 2006 at the site of discovery, showing the Yoldia Sea clay layer (light grey) in which the bone was found (Photo: Veikko Sorsa, University of Helsinki). (d) Some of the sediment sample on which the diatom and pollen analyses were performed. 


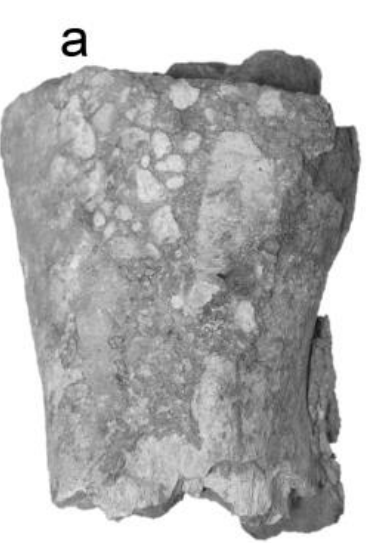

b

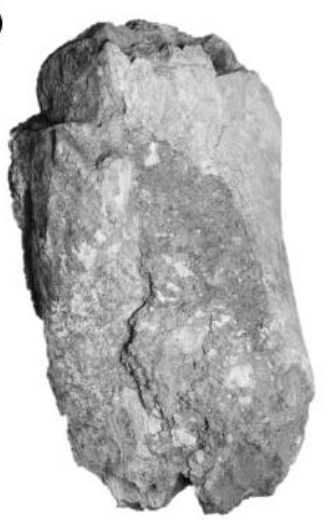

e

899

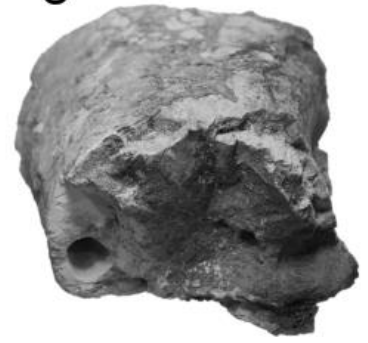

C

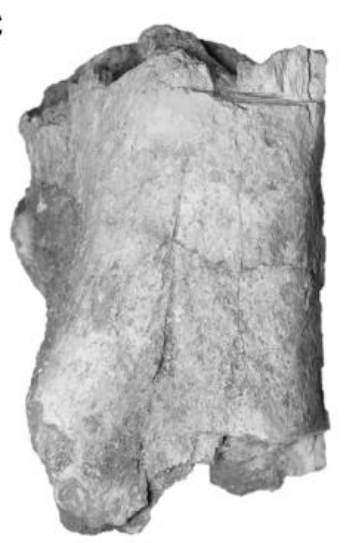

d

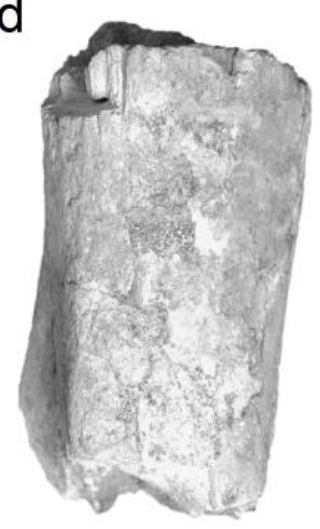

900

901 Figure 2. The Suomusjärvi proboscidean fossil (left humerus diaphysis) in (a) cranial, (b) left 902 lateral, (c) caudal, (d) right lateral and (e) craniodistal view.

903

904

905

906

907

908

909

910

911

912

913

914

915 
a

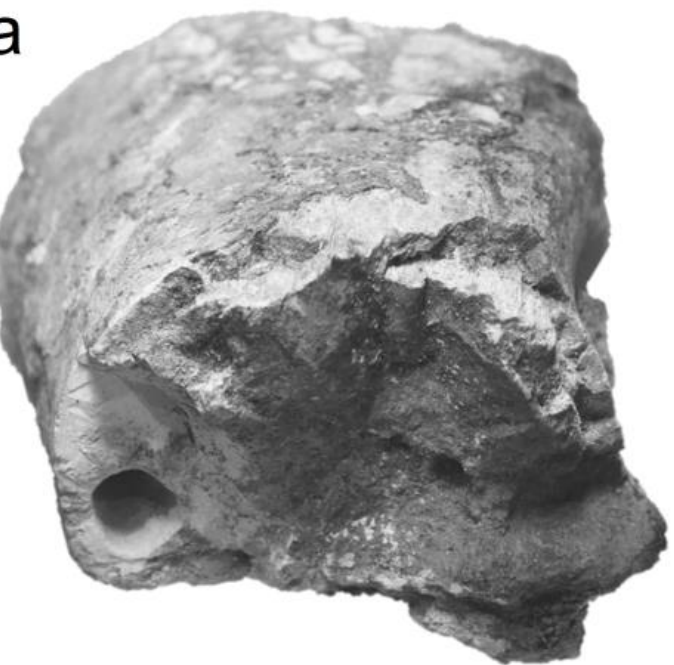

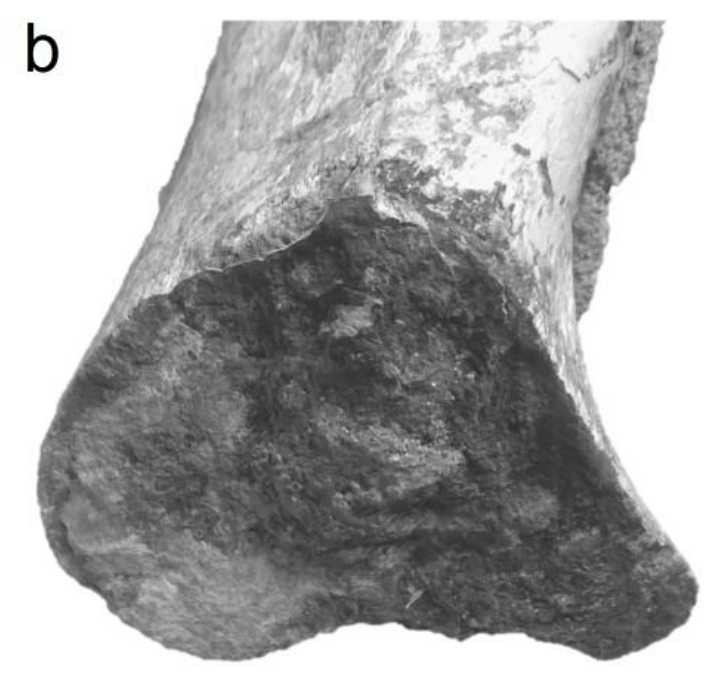

917

918 Figure 3. Visual comparison of the cross-sections of (a) the Suomusjärvi specimen and (b) a

919 fossil elephant (Elephas recki) humerus (NHM M 14691) from Olduvai, Tanzania. Note the

920 lack of prominent crista humeri in the Suomusjärvi humerus resulting in a rounded rather than

921 triangular cross-section at the mid-shaft of the bone. The elephantid humerus figure has been

922 reversed for comparison. The photos are not in the same scale. The E. recki specimen from

923 Olduvai is stored at the Natural History Museum of London.

924

925

926

927

928

929

930

931

932

933

934 


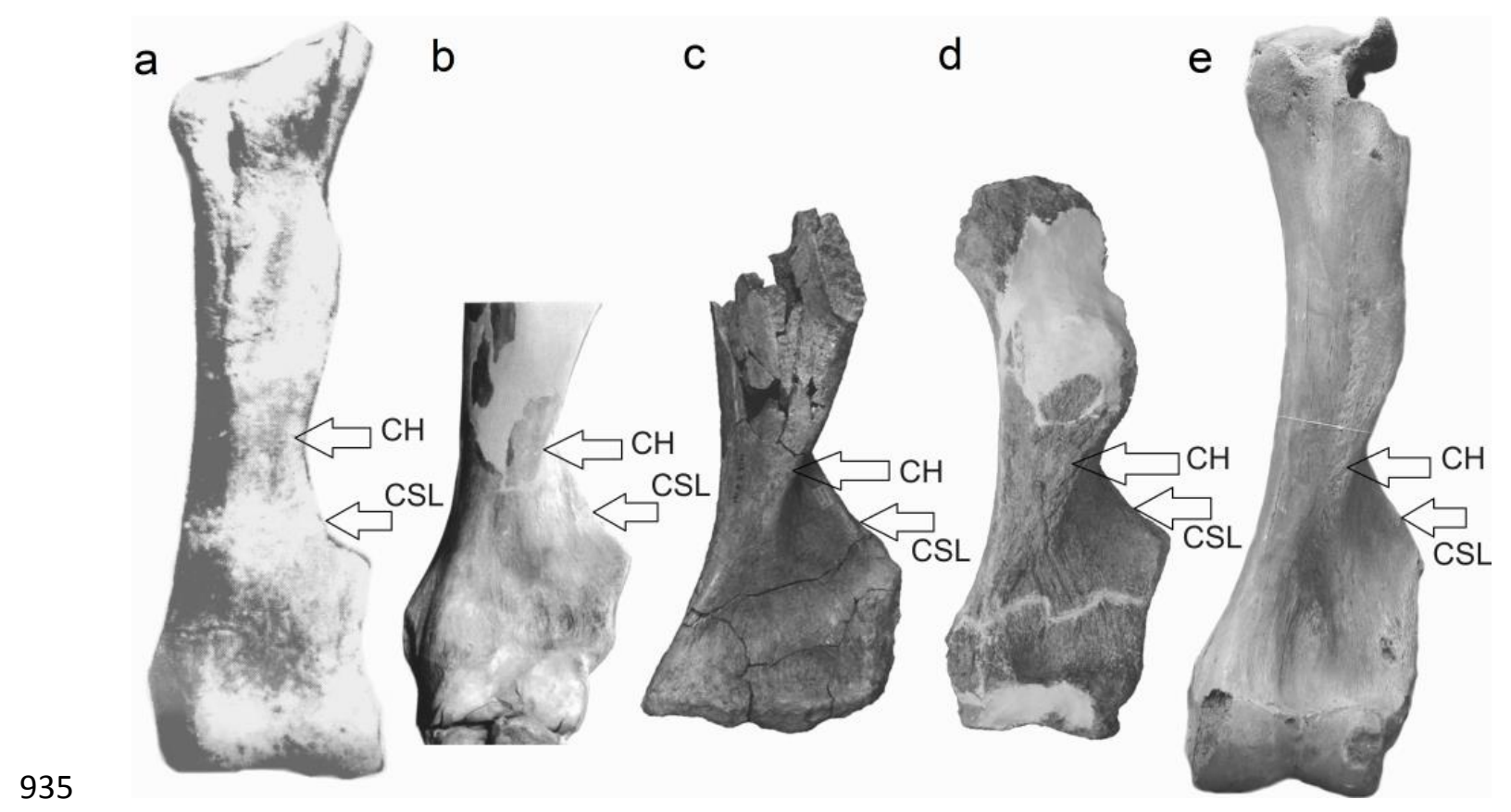

937 Figure 4. Examples of the humeri of Deinotherium (a), Prodeinotherium (b), Gomphotherium

938 (c), Mammut (d) and Mammuthus (e), with arrows pointing at the crista humeri $(\mathrm{CH})$ and the 939 crista supracondylaris lateralis (CSL). Photos $\mathbf{c}, \mathbf{d}$ and $\mathbf{e}$ are reversed in order to show the 940 features as they appear in the Suomusjärvi specimen. The photos are not to the same scale. Note 941 the strongly reduced and inconspicuous crista humeri of Deinotherium compared to the other 942 taxa. a. Deinotherium thraceiensis (Deinotheriidae) from Ezerovo, Bulgaria (Kovachev and 943 Nikolov, 2006), b. Prodeinotherium bavaricum (Deinotheriidae) from Franzensbad, Czech 944 Republic (Huttunen, 2004), c. Gomphotherium subtapiroideum (Gomphotheriidae) from 945 Sandelzhausen, Germany (Göhlich, 2010), d. Mammut americanum (Mammutidae) from 946 Hidalgo, Mexico (Bravo-Cuevas et al., 2015) and e. Mammuthus primigenius (Elephantidae) 947 (SMNS 6316.2.6.82.2) from Lampertheim, Germany (J. Saarinen, specimen stored in 948 Staatliches Museum für Naturkunde, Stuttgart). Photos are reproduced with permissions from 949 the journals $(\mathbf{a}, \mathbf{b}, \mathbf{d})$ or publishers $(\mathbf{c})$. 


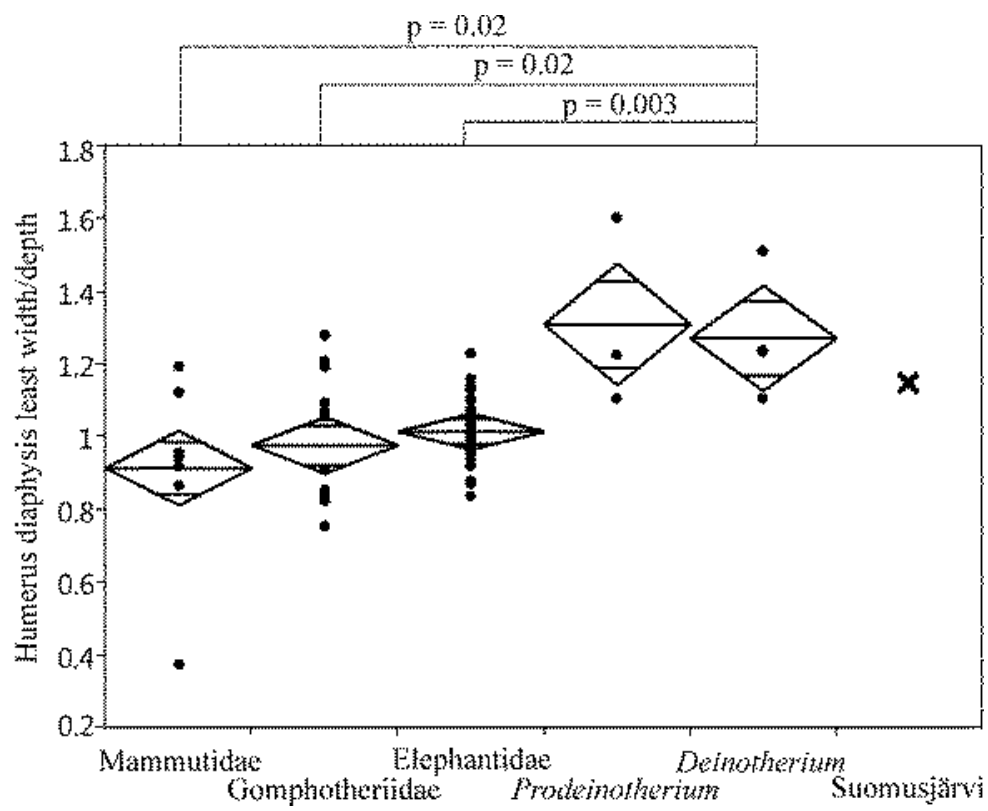

954

955 Figure 5. Minimum width / minimum depth of the narrowest part of humerus diaphysis for 956 proboscidean groups. Mean values are indicated by mean diamonds in which the middle line shows the mean and the upper and lower lines represent $95 \%$ confidence limits. The deinotheres have on average larger width in relation to depth than the other families (significant differences 959 in mean width/depth between Deinotherium and Elephantidae, Gomphotheriidae and 960 Mammutidae are indicated as p-values in the figure), and the Suomusjärvi specimen fits closer 961 to the average of deinotheres than to the average of the other proboscideans in this respect. The 962 data for this comparison is gathered from literature (Göhlich, 1998, 2010; Huttunen and Göhlich, 2002; Christiansen, 2004; Kovachev and Nikolov, 2006; Ferretti, 2010, Tsoukala and Mol, 2014; Bravo-Cuevas et al., 2015) and from specimens measured by J. Saarinen. 

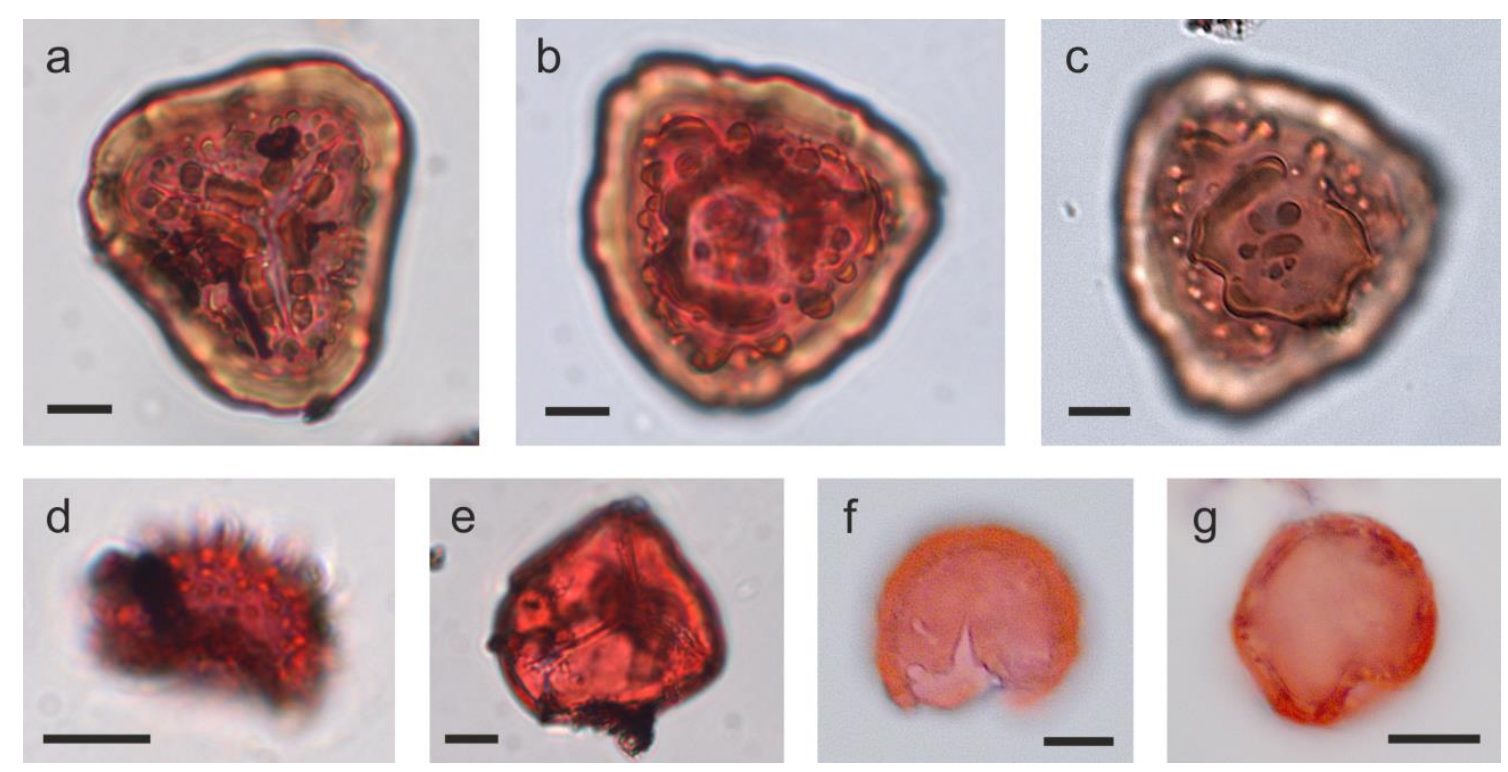

972

973 Figure 6. Micrographs of Miocene palynomorphs found in the Suomusjärvi bone: (a)

Pteridacidites variabilis, specimen 1, proximal view, 400× magnification; (b) Pteridacidites variabilis, specimen 2, distal view, 400×; (c) Pteridacidites variabilis, specimen 3, distal view on surface ornamentation, 400×; (d) Echinatisporis sp., 600×; (e) indet. trilete spore, 400×; (f) indet. Cupressaceae, specimen 1, 400×; (g) indet. Cupressaceae, specimen 2, 1000x in oil immersion. Scale bars $=10 \mu \mathrm{m}$.

979

980

981

982

983

984

985

986

987

988 


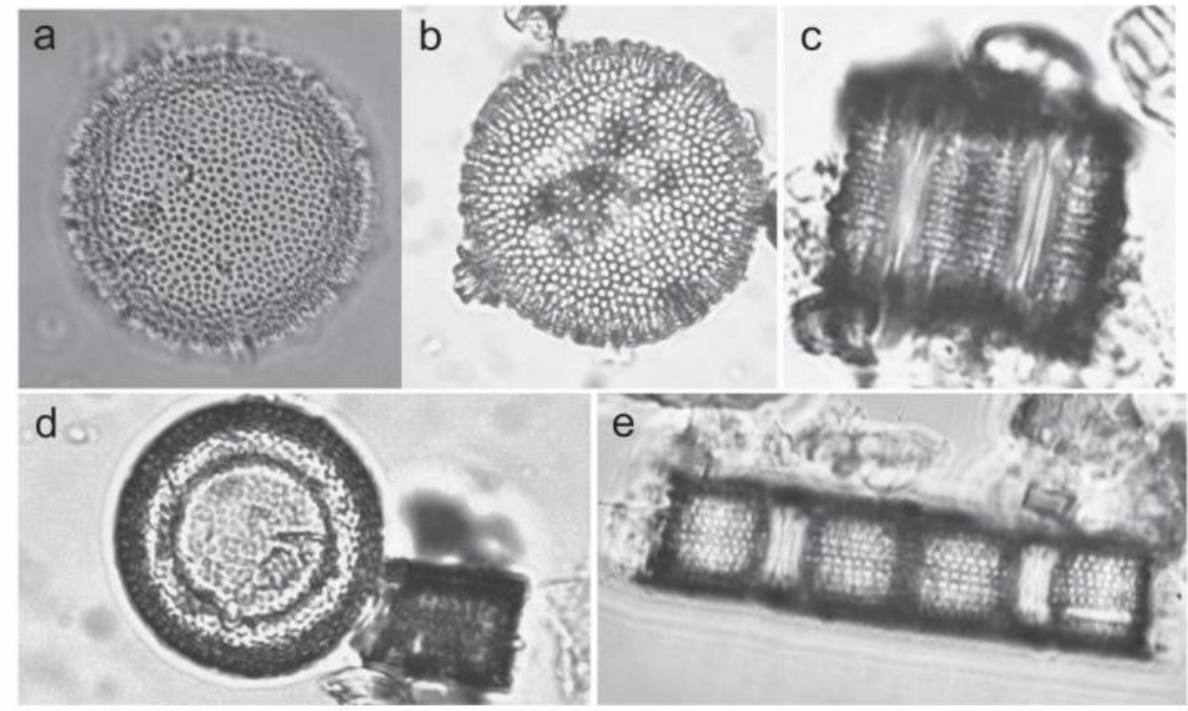

991

992 Figure 7. The most common diatom species in the sample: (a, b, d) Alveolophora sp. (valve

993 view); (c) Alveolophora sp. (mantle view); (e) Aulacoseira granulata (mantle view).

994

995

996

997

998

999

1000

1001

1002

1003

1004

1005

1006

1007

1008 


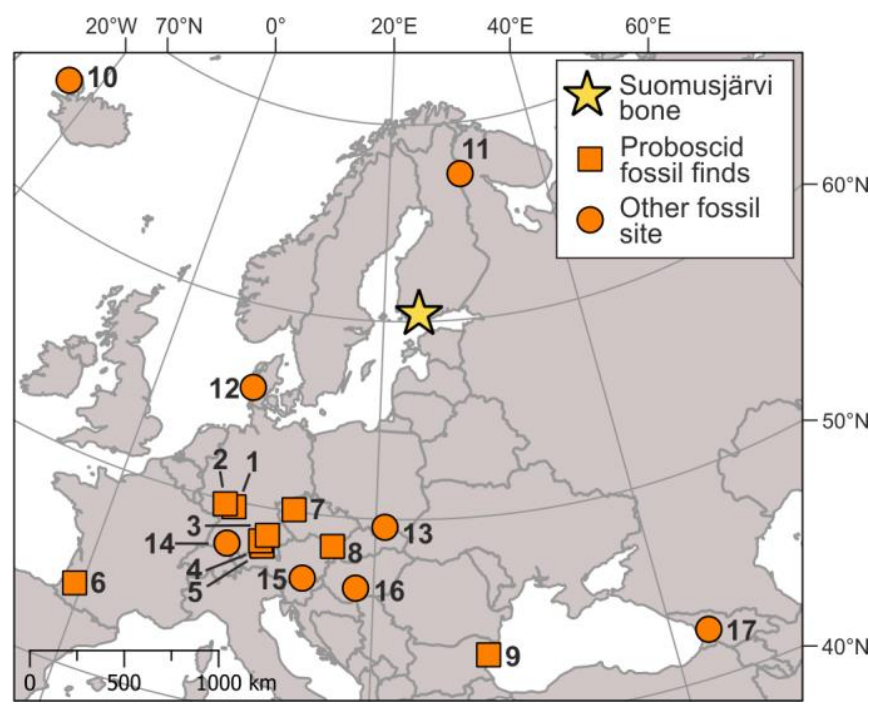

1010

1011 Figure 8. Map showing the site of bone discovery and locations of Neogene/Miocene proboscid 1012 and other fossil sites referenced in the text. Names and references for the numbered sites: 1, 1013 Eppelsheim (Fortelius, 2015); 2, Dorn-Dürkheim 1 (Fortelius, 2015); 3, Sandelzhausen 1014 (Fortelius, 2015); 4, Unterzolling (Fortelius, 2015); 5, Munich (Fortelius, 2015); 6, Sansan 1015 (Fortelius, 2015); 7, Franzensbad (Fortelius, 2015); 8, Kettlasbrunn (Fortelius, 2015); 9, 1016 Ezerovo (Fortelius, 2015); 10, Iceland (Grímsson et al., 2007); 11, Naruskajärvi (Hirvas and 1017 Tynni, 1976; Tynni, 1982); 12, Sønder Vium (Larsson et al., 2006); 13, Nowy Sącz and Nowy 1018 Targ-Orawa Basins (Stuchlik and Shatilova, 1987); 14, Bohlinger Schlucht (Uhl et al., 2006); 1019 15, Lavanttal Basin (Grímsson and Zetter, 2011; Grímsson et al., 2011); 16, Pannonian Basin (Jiménez-Moreno et al., 2005); 17, Western Georgia (Stuchlik and Shatilova, 1987; Shatilova and Stuchlik, 1996). 